УДК 159.923:378.011.3-051:005.336.5

DOI https://doi.org/10.51547/ppp.dp.ua/2021.1.9

\title{
Заболоцька Світлана Ігорівна,
}

кандидат психологічних наук, доцент кафедри психології

Дрогобицького державного педагогічного університету імені Івана Франка

\section{Заміщак Марія Ігорівна,}

кандидат психологічних наук, доцент кафедри психології

Дрогобицького державного педагогічного університету імені Івана Франка

\section{ПСИХОЛОГІЧНІ ЧИННИКИ Й УМОВИ СТАНОВЛЕННЯ КОМПЕТЕНТНОГО МАЙБУТНЬОГО ПЕДАГОГА}

\author{
PSYCHOLOGICAL FACTORS AND CONDITIONS OF FORMATION \\ OF A COMPETENT FUTURE TEACHER
}

\begin{abstract}
У статті проаналізовано психологічні чинники й умови становлення компетентного майбутнього педагога. Констатується, щчо професійна компетентність формується, розвивається, проявляється та поглиблюється. Таке розуміння є надзвичайно важливим для створення моделі компетентного випускника закладу вищьӧ освіти у сфері навчання й самонавчання, розвитку й саморозвитку, виховання й самовиховання, формування критеріїв оцінки досягнень суб'єктів освітнього прочесу, здорової педагогічної діяльності майбутнього вчителя. Зазначається, щзо компетентність педагога розглядається як система внутрішніх психічних властивостей і станів особистості вчителя, його готовності до здійснення професійної діяльності й здібності виробляти необхідні для иъього дії. Охарактеризовано та виділено два види компетентності: професійну й психологічну. Підкреслено, щз психолого-педагогічний підхід у структурі професійної компетентності педагога виділяє чотири блоки: професійні знання, професійні уміння; професійні позиції; установки вчителя й особистісні особливості, щзо забезпечують оволодіння вчителем професійними знаннями та професійними вміннями. Стверджується, щзо перспективи розвитку вищої педагогічної освіти передбачають поступовий перехід від пояснювально-репродуктивного типу навчання до створення оптимальних умов для інтелектуального розвитку студента, творчого застосування ним засвоєних знань, оволодіння методами самостійної пізнавальної діяльності, усвідомлення потреби постійно розвиватися й самовдосконалюватися. Майбутній педагог повинен здобути достатні навички самостійної роботи, уміння раціонально планувати свій робочий час $і$ займати активну позицію щзодо педагогічної діяльності. Пропонуються провідні чинники й умови, щчо забезпечують становлення компетентного майбутнього педагога щзодо педагогічної діяльності. Констатується, щу відповідні складники в структурі підготовки майбутніх педагогів сприятимуть оволодінню повноцінною здоровою педагогічною діяльністю студентом-педагогом.
\end{abstract}

Ключові слова: професійна компетентність, психологічні чинники, психологічні умови, майбутній педагог, компетентнісний підхід.

The article analyzes the psychological factors and conditions of becoming a competent future teacher. It is stated that professional competence is formed, developed, manifested and deepened. This understanding is extremely important for creating a model of a competent graduate of higher education in the field of education and self-study, development and self-development, education and self-education, the formation of criteria for assessing the achievements of the educational process, healthy teaching of future teachers. It is noted that the competence of the teacher is considered as a system of internal mental properties and states of the teacher's personality, his readiness to carry out professional activities and the ability to perform the necessary actions. Described and highlighted two types of competence: professional and psychological. It is emphasized that the psychological and pedagogical approach in the structure of professional competence of a teacher is divided into four blocks; professional knowledge, professional skills; professional positions; teacher's attitudes and personal characteristics that ensure the teacher's mastery of professional knowledge and professional skills. It is argued that the prospects for higher pedagogical education include a gradual transition from explanatory-reproductive type of education to creating optimal conditions for intellectual development of students, creative application of acquired knowledge, mastering the methods of independent cognitive activity, awareness of the need to constantly develop and improve. The future teacher must acquire sufficient skills of independent work, the ability to rationally plan their working hours and take an active position in teaching. The leading factors and conditions providing formation of the competent future teacher to pedagogical activity are offered. It is stated that the relevant components in the structure of training of future teachers will contribute to the mastery of a full healthy pedagogical activity by a student-teacher.

Key words: professional competence, psychological factors, psychological conditions, future teacher, competence approach. 
В умовах сучасного закладу вищої освіти постає актуальна проблема підготовки компетентного майбутнього педагога до здорової педагогічної діяльності. Предметом наукових дискусій залишається питання особистісних здатностей у студентів-педагогів, професійних та особистісних здібностей майбутніх педагогів, моделей, засобів і шляхів становлення педагогічної майстерності, збереження стійких психічних станів i властивостей, які сприятимуть ефективній реалізації компетентнісного підходу.

Феномен «професійна компетентність» охоплює базові характеристики: знання, норми, цінності, уміння й навички, досвід у педагогічній діяльності, особистісні здатності, педагогічні здібності, професійна культура. Професійна компетентність формується, розвивається, проявляється та поглиблюється [5, с. 106]. Саме таке розуміння є надзвичайно важливим для створення моделі компетентного випускника закладу вищої освіти у сфері навчання й самонавчання, розвитку й саморозвитку, виховання й самовиховання, формуванні критеріїв оцінки досягнень суб'єктів освітнього процесу, здорової педагогічної діяльності майбутнього вчителя. Сучасні науковці, зокрема I. Бех, В. Бондар, Л. Долинська, В. Семиченко, стверджують, що оволодіння майбутніми педагогами теоретичними знаннями - це їх включення в процес активного творення інформації [5, с. 106]. В образі професійно-компетентного педагога повинні гармонізуватися всі компоненти як поєднання особистісних і професійних властивостей, а їх матеріальними формами є знання, уміння, обсяг навичок, активність, самостійність, самонавчання, індивідуальність, а також професійні якості - комунікативність, тактовність, емоційна врівноваженість, адекватність планування, доброзичливість [3].

Ю. Варданян [3] розглядає компетентність педагога як систему внутрішніх психічних властивостей і станів особистості вчителя, його готовності до здійснення професійної діяльності й здібності виробляти необхідні для цього дії. Інші науковці цього підходу виділяють такі види компетентності в діяльності педагога: спеціальну та професійну в межах дисципліни, що викладається, методичну в розумінні способів, формування знань, умінь; соціально-психологічну в орієнтованості в процесах спілкування; диференційно-психологічну - знання мотивів, здібностей учнів; аутопсихологічну - розуміння переваг і недоліків власної діяльності й особистості.

Прихильники соціально-психологічного підходу [11] розглядають поняття компетентності
3 погляду комунікативного складника, виділяючи комунікативну, соціальну, соціально-психологічну та соціально-перцептивну компетентність. Нині під комунікативною компетентністю більшість науковців розуміє вміння спілкуватися, тобто здатність установлювати контакти 3 людьми, готовність особистості до спілкування й розвиток відповідних цінностей та адекватних умінь. Так, на думку М. Обозова [10], комунікативна компетентність може бути визначена у двох аспектах: як орієнтованість особистості в різних ситуаціях спілкування, заснована на знаннях і чуттєвому досвіді, і як здатність ефективно взаємодіяти 3 навколишніми завдяки розумінню себе й інших при постійному змінюванні психічних станів, міжособистісних стосунків та умов соціального оточення.

3 погляду соціально-психологічного підходу структурні компоненти комунікативної компетентності представлені у вигляді єдності цінностей, цілей, контактів, досвіду, умінь і навичок. Причому особливу увагу приділяють здібностям i комунікації, що включає як спілкування між людьми, так і всі види інформаційних зв'язків і відносин, завдяки яким людина отримує інформацію про зміни, дізнається про значення того, що відбувається, адаптуючись до нових умов. С. Головін пропонує свій погляд на комунікативну компетентність: уміння орієнтуватися в соціальних ситуаціях; уміння правильно визначати особистісні та емоційні особливості; уміння вибирати адекватні способи поведінки 3 ними й реалізовувати їх у процесі взаємодії [17].

Ю. Жуков, Л. Петровська [4] використовують поняття «компетентність у спілкуванні» й визначають іï як «здатність установлювати та підтримувати потрібні контакти 3 іншими людьми», ставлять завдання ii розвитку за допомогою вдосконалення перцептивного, комунікативного й інтерактивного складників згідно зі структуруванням функцій спілкування. Із цього погляду компетентність у спілкуванні передбачає готовність і вміння будувати контакт на різній психологічній дистанції. Зазначається, що не володіння якоюсь однією позицією як найкращою, а вміння гнучко, адекватно змінювати ці позиції є істотним показником компетентного спілкування [4]. До того ж, на думку авторів [4], комунікативна компетентність не виникає на порожньому місці, вона формується. Основу формування становить досвід людського спілкування, який, 3 одного боку, соціальний (включає норми й цінності культури), з іншого боку, індивідуальний (грунтується на індивідуальних комунікативних здібностях 
і психологічних подіях, пов'язаних зі спілкуванням у житті особистості).

У психологічній літературі соціальну компетентність розглядають або як інтегративне поняття, що свідчить про рівень соціалізації, або як особистісну властивість, що забезпечує взаємодію людини зі світом на основі їі ставлення до себе, суспільства, інших, до діяльності. Останнім часом соціальна компетентність співвідноситься 3 поняттям «упевненість у собі». Так, на думку Г. Сівкової [16], соціальна компетентність передбачає наявність впевненої поведінки, при якій різні навички у сфері стосунків з людьми автоматизувалися й дають можливість гнучко змінювати свою поведінку залежно від ситуації. Ця ж думка виражена й у В. Ромека [13], який розглядає соціальну компетентність як результат особливого стилю - упевненої поведінки, при якому навички впевненості автоматизовані й дають можливість гнучко змінювати стратегію та плани поведінки 3 урахуванням вузького (особливості соціальної ситуації) і широкого (соціальні норми та умови) контексту.

Наступним видом компетентності, що розглядається $з$ позиції стосунків між людьми, є соціально-психологічна компетентність як здатність індивіда ефективно взаємодіяти 3 оточуючими людьми в системі міжособистісних відносин. А. Безносова вважає, що соціально-психологічна компетентність - це не тільки володіння знаннями, що дають змогу судити про соціально-психологічні явища, а й здатність людини реагувати в заданих ситуаціях певним чином [1].

В. Спірідонов [18] описує два різні сенси компетентності: відносний та абсолютний. У першому випадку автор під компетентністю розуміє високий рівень розвитку навички, способу розв'язання завдання або цілісної діяльності, що виражається в ефективності, швидкості, точності їх виконання. Компетентність, на думку В. Спірідонова, $\epsilon$ психологічною системою забезпечення якості й можливості подолання проблемних ситуацій, оцінюється як із процесуальних, так і з результативних показників. Компетентність, на думку автора, вбирає в себе як знання, уміння, навички, певний рівень розвитку різних здібностей, які забезпечують високі результати, так і професійне ставлення, яке описується в термінах самооцінки, рівня домагань і самоефективності. Також науковець акцентує [18], що розвинена компетентність пов'язана з володінням певним професійним мовленням і набором якихось спеціальних уявлень чи «схем» у тому числі про самого себе. Автор уважає [18] важливими складниками компетент- ності наявність самої потреби бути компетентним (мотиваційний аспект), а також бажання самостійно формулювати завдання й долати труднощі у вирішенні проблемних ситуацій. У другому випадку компетентність є явищем абсолютним (вона або $\epsilon$, або немає), а критерії, які вказують на iï наявність, не пов'язані з параметрами процесу або результатом діяльності.

Отже, можна виділити два види компетентності: професійну та психологічну. А. Маркова [9] у професійній компетентності виділяє спеціальну професійну, що передбачає володіння власне професійною діяльністю на достатньо високому рівні, здатність проектувати свій подальший професійний розвиток, соціальну - уміння ефективно спільно працювати, володіння прийомами особистісної саморегуляції, самовираження й саморозвитку, засобами протистояння професійному вигоранню особистості, здатність приймати рішення, самостійно здобувати нові знання, уміння та навички, й індивідуальну, яка передбачає готовність до професійного зростання, уміння організувати раціонально свою працю, мотивація досягнення, прагнення до якості своєї роботи, оптимізм. Наявність усіх аспектів компетентності, на думку автора, означає досягнення особистістю зрілості в професійній діяльності, характеризує становлення особистості й індивідуальності професіонала [9].

Автори психолого-педагогічного підходу в структурі професійної компетентності вчителя виділяють чотири блоки; професійні знання та професійні вміння; професійні позиції; установки вчителя й особистісні особливості, що забезпечують оволодіння вчителем професійними знаннями та професійними вміннями $[9 ; 10]$. У змісті професійної компетентності автори виділяють процесуальні й результативні показники, а компетентність учителя розглядають 3 боку педагогічної діяльності та результату навченості й здатності до навчання школярів.

В. Спірідонов виділяє в структурі компетентності об'єднання емоційних, мотиваційних і когнітивних структур [18]. Дж. Равен [12] уважає, що компетентність - це спеціальна здатність, необхідна для ефективного виконання певних дії в певних галузях і вимагає спеціальних знань, певних способів мислення, а також усвідомлення відповідальності за свої дії. Автор виділяє вищу компетентність, яка незалежно від того, у якій конкретній сфері вона виявляється, припускає наявність в особистості високого рівня ініціативи, здатності організувати інших для досягнення поставлених цілей, готовність оцінювати й аналізувати 
соціальні наслідки. Причому автор підкреслює [12], що «види компетентності» - «мотивовані здібності».

На нашу думку, у підготовці майбутніх педагогів має значення метапредметний підхід [8], оскільки він висуває вимоги дуже глибокого знання свого предмета, що, власне, і дає змогу «діяльнісно перепрацьовувати» навчальний матеріал і заново його інтерпретувати з погляду діяльнісних одиниць змісту. Цей підхід допомагає уникати небезпек вузькопредметної спеціалізації, при цьому водночас не передбачає відмови від предметної форми, а, навпаки, припускає розвиток іiї на рефлексивних засадах [8].

Для педагога особливо важливо й значуще, оскільки його діяльність має носити стосовно нерегламентований характер, 3 одного боку, і чітко структурований, 3 іншого боку, а також вирізнятися свободою та широкими можливостями вибору форм навчання, методів роботи на заняттях: норм оцінювання результатів власної діяльності.

Зауважимо, що формування особистості майбутнього педагога проходить під великим впливом особистості й діяльності викладача, який через себе транслює соціальний освітній досвід.

Сьогодні в новій українській школі педагогічну діяльність здійснює педагог із розвиненою і здоровою особистістю, який оволодів відповідними компетенціями, здатний долати труднощі, забезпечувати виховання здорової особистості школярів, створювати умови для особистої свободи й відповідальності, моральності й самодостатності, уміти запобігати маніпулятивним впливам з боку оточення. Сам педагог повинен швидко вміти приймати рішення, виразно та чітко висловлювати свої думки, легко адаптовуватися до нової ситуації, міцно засвоювати систему моральнодуховних цінностей, адекватно керувати своєю поведінкою.

Рівень розуміння дитини залежить від уміння проникнути у внутрішній світ особистості учня. Повноцінну особистість може виховати лише вихований, психічно, психологічно, соціально, морально та духовно розвинений наставник. Це актуалізує значення спрямованості особистості педагога (світогляд, головні потреби, інтереси, цілі), його ставлення до соціального оточення й соціальну активність, психічне та психологічне здоров'я, моральний і духовний потенціал тощо [14].

Варто сказати про професійну педагогічну майстерність - вершину професіоналізму, стверджує М. Савчин, який акцентує, що діяльність педагога зорієнтована на гарантований педагогіч- ний результат. Педагогічна майстерність неможлива як без розвитку педагогічних спеціальних здібностей, які є основною вимогою діяльності, так і без відповідних цим вимогам знань і вмінь. Вона виражається в умінні бачити й формулювати педагогічні завдання на основі аналізу педагогічних ситуацій і знаходити оптимальні способи їх вирішення [15].

Отже, щоб допомогти студентам у засвоєнні знань, розвинути педагогічні та індивідуальні якості, викладач сам повинен відповідати цим вимогам.

Соціальний статус майбутнього педагога передбачає значне розширення сфери навчання, спілкування й діяльності. Студент-педагог починає розуміти свою належність до нового педагогічного колективу, входить у широке коло суспільних відносин. Саме тому в студента-педагога розширюється світогляд, відбувається формування характеру, вибудовуються життєві плани, підвищується відповідальність і вимогливість до себе. Молоді люди намагаються знайти своє місце в житті, відповідати власним уподобанням та інтересам. Отже, перспективи розвитку вищої педагогічної освіти передбачають поступовий перехід від пояснювально-репродуктивного типу навчання до створення оптимальних умов для інтелектуального розвитку студента, творчого застосування ним засвоєних знань, оволодіння методами самостійної пізнавальної діяльності, усвідомлення потреби постійно розвиватися й самовдосконалюватися. Майбутній педагог повинен здобути достатні навички самостійної роботи, уміння раціонально планувати свій робочий час і займати активну позицію щодо педагогічної діяльності. Формування сучасного майбутнього педагога при високій мобільності технологій, непередбачуваності економічних процесів можливе лише за бажання та вміння вчитися самостійно протягом усього професійного життя, орієнтуватися в швидко плинних умовах життя. Процеси глобалізації в усіх сферах суспільного життя вимагають від молодої людини вміння успішно та ефективно інтегруватися в різні соціуми, самовизначатися в житті, активно діяти, ураховуючи постійні зміни на світовому ринку праці. Формування педагогічної компетентності відбувається насамперед завдяки докладеним власним особистісним зусиллям студента. Протягом навчання компетентність студента-педагога зростає через засвоєння спеціальних і загальнокультурних знань, оволодівання різними практичними методами роботи, появу професійної критичності мислення. 
Провідними чинниками й умовами, що забезпечують становлення компетентного майбутнього педагога щодо педагогічної діяльності, можна вважати такі:

1) високий рівень професіоналізму викладача закладу вищої освіти, який забезпечує продуктивність процесу становлення майбутнього компетентного педагога;

2) взаємопов'язаність змісту й форм підготовки характеру майбутньої педагогічної діяльності;

3) володіння академічними та дидактичними знаннями, базовими вміннями й навичками індивідуальної та групової роботи з різними категоріями школярів, наявність особистого бачення й власного стилю навчальної, виховної та розвивальної роботи з вихованцями;

4) здатність до саморозвитку та самовдосконалення в умовах здійснення педагогічної діяльності;
5) можливість постійного педагогічного спілкування, отримання професійної допомоги й підтримки;

6) створення умов для постійного поповнення психолого-педагогічних знань, розвитку й удосконалення педагогічних умінь і навичок;

7) моделювання життєвих і педагогічних ситуацій, де реалізується найбільш значущих особистісних і педагогічних проблем самого педагога.

Отже, структура підготовки майбутніх педагогів сприятиме оволодінню повноцінною здоровою педагогічною діяльністю студентом-педагогом, включає такі основні складники: а) освітній, який грунтується на моделі становлення майбутнього педагога в процесі психолого-педагогічної підготовки, б) особистісний, що будується на характеристиці здорової особистості, в) діяльнісний, який формується на моделі індивідуального стилю педагогічного мислення, взаємодії, діяльності й уміння вирішувати конкретні педагогічні завдання.

\section{СПИСОК ЛІТЕРАТУРИ:}

1. Безносова А.В. Формирование социально-психологической компетентности в конфликте в подростковом возрасте. Толерантность и проблемы идентичности. Ижевск, 2005. С. 64-66.

2. Бреславська Г.Б. Формування культури дозвілля, як складової професійної компетентності майбутніх вчителів. Формування професійної компетентності вчителя в умовах вищого навчального закладу : науковий посібник / під заг. ред. проф. С.І. Якименко. Київ : Видав. дім «Слово», 2011. С. 381.

3. Варданян Ю.В., Кильмяшкина Т.А. Модель вузовской образовательной системы становления психологической компетентности педагога. Психология в вузе. 2008. № 2. С. 5-17.

4. Жуков Ю.М. Петровская Л.А., Растенников П.В. Диагностика и развитие компетентности в общении. Москва : МГУ, 1990. 104 с.

5. Загайнов Р.М. Проклятие профессии: бытие и сознание практического психолога. Москва : Смысл, 2001. 574 с.

6. Иванова Е.М. Основы психологического изучения профессиональной деятельности. Москва : МГУ, 1987. 207 с.

7. Кабардов М.К., Арцишевская Е.В. Типы языковых и коммуникативных способностей и компетенций. Вопросы психологии. 1996. № 1. С. 259-288.

8. Кузнецова Н.С. Метапредметный подход в транскультурном образовании иностранных студентов как единство модульного обучения и внеаудиторной деятельности. Проблемы и перспективы развития образования : материалы Междунар. заоч. науч. конф. Пермь : Меркурий, 2012. С. 16-19.

9. Маркова А.К. Психология профессионализма. Москва : Просвещение, 1996. 254 с.

10. Митина Л.М. Психология труда и профессионального развития учителя. Москва : Издат. центр «Академия», 2004. 320 с.

11. Обозов Н.Н. Психологическая культура взаимных отношений : учебное пособие. Москва : Высшая школа, 1986. $45 \mathrm{c}$

12. Равен Дж. Компетентность в современном обществе: выявление, развитие, реализация. Москва : Когито-Центр, 2002. 396 с.

13. Ромек В.Г. Предпосылки и критерии профессионализации психолога-тренера. Профессиональное становление специалиста : сборник науч. трудов. Ростов-на-Дону : Фолиант, 2006. С. 99-110.

14. Савчин М.В. Психологія відповідальної поведінки : монографія. Івано-Франківськ : Місто НВ, 2008. 280 с.

15. Савчин М.В. Теоретико-методологічні засади створення та реалізації програми особистісно-професійного розвитку майбутнього педагога. Особистісно-професійний розвиток майбутнього педагога : монографія / за ред. проф. М.В. Савчина. Дрогобич : ВВДДПУ ім. І. Франка, 2014. С. 9-18.

16. Сивкова Г.И. Социальная компетентность. Вакансия. 2001. № 13 (71). С. 10-12.

17. Словарь практического психолога / сост. С.Ю. Головин. Минск : Харвест, 1998. 799 с.

18. Спиридонов В.Ф. Психологические механизмы профессионального развития. Проблемы психологии развития. Москва, 2000. С. 364-380.

19. Шуляр В.І. Модель професійно-фахової компетентності сучасного вчителя в умовах неперервної освіти. Формування професійної компетентності вчителя в умовах вищого навчального закладу : науковий посібник / під заг. ред. проф. С.І. Якименко. Київ : Видав. дім «Слово», 2011. С. 106. 